\title{
Identifikasi Senyawa Flavonoid dan Efek Terapi Ekstrak Etanol 70 \% Umbi Binahong (Anredera cordifolia (Ten.) Steenis) Terhadap Kadar Glukosa Darah dan Aktifitas SOD (Superoksida dismutase) Jantung Tikus yang Diinduksi Aloksan
}

\author{
Andrieyani, Ahmad Hanapi, A.Ghanaim Fasya, Hafidatul Hasanah \\ Jurusan Kimia, Fakultas Sains dan Teknologi Universitas Islam Negeri Maulana Malik Ibrahim Malang \\ Email: ndrieyanni@gmail.com
}

\begin{abstract}
The aims of this research was to identify the flavonoid content in binahong tuber and determine the effect of $70 \%$ ethanol extract of binahong tuber on blood glucose level and SOD activity in rats (Rattus norvegicus) induced alloxan. The extract was maceration and then used to test the classes of its compound content using phytochemical test, the flavonoid compound contained in the extract was separated by analytic thin layer chromatography (TLC) and antidiabetic effect against rats induced alloxan with dose of alloxan was $32 \mathrm{mg}$ / $200 \mathrm{~g} \mathrm{BW}$. The results showed that the $70 \%$ ethanol extract of binahong tuber contains flavonoids, alkaloids, tannins, saponins and terpenoids. Butanol: acetic acid: water (4: 1: 5) was the best eluent for separation of flavonoid compound in extract and binahong tuber extracts treatment with variation of extract dose, 25, 60 and $75 \mathrm{mg} / \mathrm{kg} \mathrm{BW}$, reduced the blood glucose levels and increased the SOD (Superoxide dismutase) activity of rat, that are 5,$511 ; 5,217$ and $4,942 \mathrm{u} / \mathrm{mL}$ respectively.
\end{abstract}

Keywords: alloxan, antidiabetic, flavonoids, binahong tubers, SOD

\begin{abstract}
Abstrak
Penelitian ini bertujuan untuk mengidentifikasi flavonoid serta mengetahui pengaruh pemberian ekstrak etanol $70 \%$ umbi binahong terhadap kadar glukosa darah dan aktifitas SOD pada jantung tikus yang diinduksi aloksan. Ekstraksi didapatkan dari hasil maserasi yang dilanjutkan dengan uji fitokimia reagen, pemisahan flavonoid dengan kromatografi lapis tipis (KLT) analitik dan dilakukan pengujian antidiabetes terhadap tikus yang terinduksi aloksan dengan dosis $32 \mathrm{mg} / 200 \mathrm{~g}$ BB. Hasil penelitian didapatkan golongan senyawa aktif yaitu senyawa flavonoid, alkaloid, tanin, saponin dan terpenoid. Eluen terbaik dari pemisahan senyawa flavonoid adalah butanol: asam asetat: air (4:1:5) dan pengujian antidiabetes setelah diterapi menggunakan ekstrak etanol $70 \%$ umbi binahong dosis 25,50 dan $75 \mathrm{mg} / \mathrm{kg} \mathrm{BB}$ telah memberikan pengaruh penurunan kadar glukosa darah dan peningkatan aktifitas SOD (Superoksida dismutase) pada jantung tikus berturut-turut sebesar 5,511; 5,217 dan $4,942 \mathrm{u} / \mathrm{ml}$ dengan dosis terbaik yaitu $25 \mathrm{mg} / \mathrm{kg}$ BB.
\end{abstract}

kata kunci: aloksan, antidiabetes, flavonoid, umbi binahong, SOD

\section{PENDAHULUAN}

Diabetes mellitus merupakan suatu sindrom yang ditandai hiperglikemia kronis dengan gangguan metabolisme karbohidrat, lemak, dan protein yang disebabkan berkurangnya sekresi insulin oleh sel-sel $\beta$ pulau langerhans atau karena kerusakan jaringan akibat stres oksidatif yang timbul bila kecepatan pembentukan radikal bebas melebihi kapasitas sel untuk menetralkannya (Gustaviani, 2006).

Salah satu kerusakan jaringan tersebut adalah jantung, dimana kerja jantung sebagai pemompa darah keseluruh tubuh dapat terganggu akibat tingginya kadar glukosa darah sehingga dapat meningkatkan kerja jantung 4-8 kali dari keadaan normal (Supriono, 2008). 
Untuk dapat memperbaiki serta mengurangi kerusakan sel maka diperlukannya antioksidan alami dalam tubuh untuk melawan radikal bebas yaitu Superoksida dismutase (SOD), namun kondisi diabetes melitus dapat mengakibatkan penurunan SOD sehingga perlu antioksidan dari luar tubuh untuk meningkatkan aktifitas SOD serta dapat menurunkan kadar glukosa darah seperti tumbuhan binahong (Anredera cordifolia (Ten.) Steenis). Selawa (2013), menyatakan kandungan flavonoid dalam ekstrak etanol binahong berpotensi sebagai antioksidan.

Penelitian Saleh dkk (2012), menggunakan ekstrak umbi binahong dengan dosis $25 \mathrm{mg} / \mathrm{kg}$ BB dapat menurunkan glukosa darah dengan induksi glukosa $50 \%$, dimana golongan senyawa flavonoid yang diduga dapat mengembalikan sensitifitas reseptor insulin pada sel sehingga dapat menurunkan kadar gula darah pada penderita diabetes mellitus.

Tujuan penelitian ini adalah untuk mengidentifikasi flavonoid serta mengetahui pengaruh pemberian ekstrak etanol $70 \%$ umbi binahong (Anredera cordifolia (Ten.) Steenis) terhadap kadar glukosa darah dan aktifitas SOD (Superoksida dismutase) pada tikus yang terinduksi aloksan.

\section{METODE PENELITIAN \\ Pelaksanaan Penelitian}

Penelitian dilaksanakan pada bulan Februari 2014 sampai Juni 2014 di laboratorium Kimia Organik Jurusan Kimia, laboratorium Fisiologi Hewan Jurusan Biologi Fakultas Sains dan Teknologi UIN Maulana Malik Ibrahim
Malang serta laboratorium Faal Fakultas Kedokteran Universitas Brawijaya.

\section{Alat dan Bahan}

Alat-alat yang digunakan pada penelitian ini adalah eperangkat alat gelas, rotary evaporator, neraca analitik, kertas saring, plat KLT silika gel $60 \mathrm{~F}_{254}$, bejana pengembang, lampu UV, pipa kapiler, penyaring buchner, shaker, vortex, kandang hewan coba (baki plastik), kawat, botol minum mencit, pinset, mikropipet, spuit 1 $\mathrm{mL}$, sonde lambung dan gunting steril, glucometer, spektrometer, dan tabung ependorff.

Bahan yang digunakan meliputi umbi binahong, etanol $70 \%$, kloroform, aloksan, $\mathrm{NaCl}$ fisiologis $(0,9 \%)$, PBS (phosphate buffer saline), CMC-Na 0,5\%, aquades, Xantine, Xantin oksidase, NBT, alkohol $70 \%$.

\section{PROSEDUR PENELITIAN \\ Preparasi Sampel}

Seluruh bagian dari umbi binahong dicuci dengan air, kemudian dipotong kecilkecil, sampel dipanaskan dengan terik matahari secara tidak langsung selama \pm 5 hari. Setelah itu, diblender sampai berbentuk serbuk.

\section{Analisis Kadar Air}

Serbuk umbi binahong yang didapatkan kemudian ditimbang dalam cawan konstak dan dimasukkan dalam oven dengan suhu $100-105^{\circ} \mathrm{C}$.

\section{Ekstraksi Maserasi}

Serbuk ditimbang sebanyak 500 gram dan 5 bagian lalu masing-masing diekstraksi maserasi dengan etanol $70 \%$ $300 \mathrm{~mL}$ (setiap hari dikocok dengan menggunakan shaker selama 3 jam) kemudian diekstraksi kembali 
menggunakan etanol $70 \% \quad 300 \mathrm{~mL}$ (Makalalag dkk., 2013).

Masing-masing ekstrak yang dipekatkan dengan rotary evaporator, ekstrak kemudian dialiri gas $\mathrm{N}_{2}$ sampai diperoleh ekstrak pekat etanol $70 \%$ (dengan berat konstan).

\section{Uji Fitokimia dengan Uji Reagen}

Ekstrak hasil maserasi diambil sedikit kemudian dimasukkan dalam tabung reaksi dan dilakukan uji golongan senyawa flavonoid, tanin, alkaloid, terpenoid dan saponin dengan menggunakan reagen yang sesuai.

\section{Pemisahan Senyawa Flavonoid}

Ekstrak pekat sebanyak 6 gram dihidrolisis dengan $12 \mathrm{~mL} \mathrm{HCl} 15 \%$, dan dipartisi dengan air : kloroform (1:1), ekstraksi dilakukan secara bertahap $(3 \times 35$ $\mathrm{mL}$ ), masing-masing fase dipisahkan kemudian dipekatkan dengan rotary evaporator. Kemudian ekstrak digunakan KLT Analitik dengan eluen butanol - asam asetat - aquades (BAA) (4:1:5), Etil asetat metanol (9:1) dan metanol - kloroform $(1: 39) ;(1: 9) ;(2: 3)$.

\section{Uji Antidiabetes}

Digunakan tikus sebanyak 24 ekor kemudian di bagi menjadi 6 kelompok meliputi kontrol nol tanpa perlakuan (KO), kontrol positif yang diinduksi aloksan dengan dosis $32 \mathrm{mg} / 200 \mathrm{~g} \mathrm{BB}(\mathrm{K}+)$, kontrol negatif (kontrol pelarut/CMC-Na $0,5 \%$ ) (K-), kelompok dosis $25 \mathrm{mg} / \mathrm{kg} \mathrm{BB}($ $\mathrm{D} 1)$, dosis $50 \mathrm{mg} / \mathrm{kg}$ BB (D2) dan dosis 75 $\mathrm{mg} / \mathrm{kg} \mathrm{BB}$ (D3) + CMC-Na 0,5\%.

Tikus diterapi umbi binahong selama 14 hari dan diukur kadar glukosa darah pada hari ke-1, 7 dan 14 dengan glukometer. Setelah hari ke-14 tikus dibedah untuk diambil organ jantungnya.

\section{Uji Aktifitas SOD}

\section{Preparasi Sampel}

Organ jantung direndam dengan PBS selama 5 menit dan ditimbang sebanyak $100 \mathrm{mg}$ lalu dihaluskan dan ditambah $1000 \mu \mathrm{L} \mathrm{pH} \mathrm{7,4} \mathrm{divortex} \mathrm{selama}$ 5 detik dan diambil supernatannya.

\section{Penentuan Aktivitas SOD}

Supernatan jantung diambil sebanyak 100 $\mu \mathrm{L}$ ditambahkan Xantine 100 $\mu \mathrm{L}$, Xantine oksidase $100 \mu \mathrm{L}$, NBT $100 \mu \mathrm{L}$ dan PBS sebanyak $1600 \mu \mathrm{L}$ lalu divortex selama 5 detik dengan kecepatan 2600 rpm. Setelah itu diinkubasi 30 menit, disentrifugase selama 10 menit. Blanko yang digunakan adalah PBS $\mathrm{pH}$ 7,4. Setelah itu sampel dan blanko diukur absorbansinya dengan spektofotometer UV pada panjang gelombang $580 \mathrm{~nm}$ (Sherly dkk., 2013).

Kurva standar dibuat dengan melarutkan SOD murni komersial dengan konsentrasi 5, 10, 20, 40, 80, $160 \mathrm{u} / \mathrm{ml}$, lalu diukur absorbansinya dengan panjang gelombang $580 \mathrm{~nm}$ dan dibuat kurva standar untuk menghitung aktifitas SOD pada sampel tersebut.

\section{Analisis Data}

Menggunakan analisis uji ANOVA pada tingkat kepercayaan $95 \%$ kemudian uji Duncan pada taraf nyata 0,05 .

\section{HASIL DAN PEMBAHASAN Analisis Kadar Air}

Kadar air yang diperbolehkan pada serbuk umbi binahong adalah sebesar 5,38 $\%$. 


\section{Uji Fitokimia}

Golongan senyawa yang dihasilkan meliputi flavonoid, alkaloid, tannin, terpenoid dan saponin sebagaimana ditunjukkan pada Tabel 1.

Tabel 1 Hasil pengamatan uji fitokimia

\begin{tabular}{|c|c|c|}
\hline $\begin{array}{c}\text { Golongan } \\
\text { Senyawa }\end{array}$ & Warna & Ket \\
\hline Flavonoid & Merah/Jingga & ++ \\
\hline Alkaloid & & \\
\hline Dragendorff & Endapan Jingga & + \\
\hline mayer & Endapan Kuning & + \\
\hline Tanin & Hijau Kehitaman & ++ \\
\hline Terpenoid & Cincin coklat & ++ \\
\hline Saponin & Busa Stabil & ++ \\
\hline
\end{tabular}

Ket:

++ = Kandungan senyawa lebih banyak (warna sangat pekat)

$+\quad=$ Mengandung senyawa (berwarna)

\section{Pemisahan Senyawa Flavonoid}

Pada KLTA, senyawa flavonoid didapatkan satu eluen menunjukkan hasil pemisahan baik yaitu menggunakan eluen butanol - asam asetat - air (4:5:1).

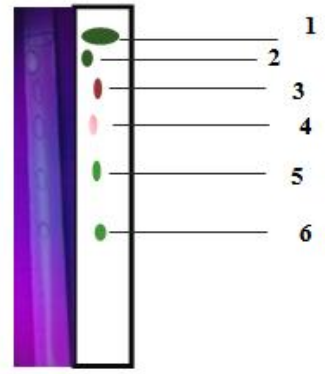

Gambar 1. KLTA BAA (4:1:5)

Hasil elusi membentuk 6 spot dengan Rf $(0,4-0,91)$. Spot yang mempunyai $\mathrm{Rf}$ terkecil $(0,4)$ menunjukkan adanya senyawaan flavonoid yang bersifat seperti sifat kepolaran fase diamnya sedangkan nilai Rf yang diatasnya $(0,55$ $0,91)$ senyawa flavonoid juga bersifat polar namun lebih mirip kepolarannya dengan fase geraknya.

Tabel 2 Hasil KLTA eluen BAA (4:1:5)

\begin{tabular}{|c|c|c|c|c|}
\hline \multirow{2}{*}{ Rf } & \multirow{2}{*}{$\begin{array}{c}\text { Warna } \\
\mathbf{U V}_{\mathbf{2 5 4} \mathbf{~ n m}}\end{array}$} & $\begin{array}{c}\text { Webelu } \\
\mathbf{m}\end{array}$ & Setelah & \multirow{2}{*}{$\begin{array}{c}\text { Dugaan } \\
\text { Senyawa }\end{array}$} \\
\cline { 3 - 4 } 0,4 & $\begin{array}{c}\text { Hijau } \\
\text { kehitaman }\end{array}$ & Hijau & Hijau tua & Flavonoid \\
\hline 0,55 & $\begin{array}{c}\text { Hijau } \\
\text { kehitaman }\end{array}$ & $\begin{array}{c}\text { Merah } \\
\text { muda }\end{array}$ & Hijau tua & Flavonoid \\
\hline 0,71 & - & - & Merah & Flavonoid \\
\hline 0,81 & - & - & $\begin{array}{c}\text { Merah } \\
\text { muda }\end{array}$ & Flavonoid \\
\hline 0,97 & Hijau & - & Hijau & Flavonoid \\
\hline 0,91 & Hijau muda & - & Hijau & Flavonoid \\
\hline
\end{tabular}

\section{Uji Antidiabetes}

Hasil penelitian menunjukkan bahwa tikus dengan laik etik 221-KEP-UB yang diinduksi aloksan dosis $32 \mathrm{mg} / 200 \mathrm{~g}$ BB secara intraperitonial dapat menyebabkan tikus menjadi diabetes, hal ini karena Aloksan menyebabkan hiperglikemia dengan diawali oleh pembentukan ROS (reaktif oksigen spesies) yang bersifat toksik, berkurangnya jumlah insulin tersebut kemudian menghambat transportasi glukosa ke sel-sel tubuh sehingga menimbulkan penimbunan glukosa dalam darah (Lenzen, 2008).

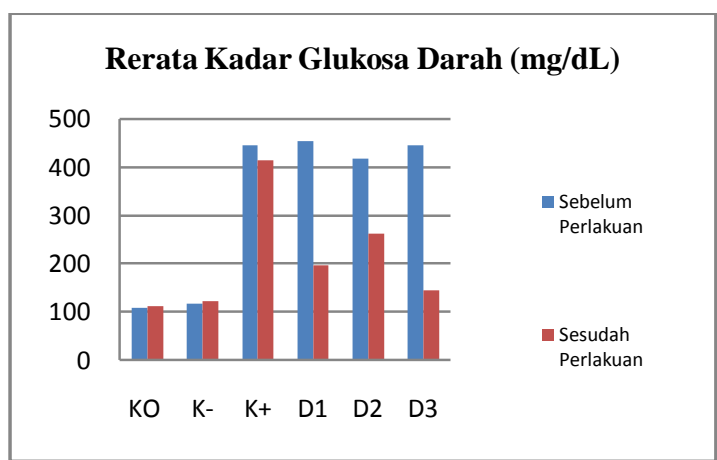

Gambar 2 Diagram batang nilai rerata kadar glukosa darah $\mathrm{H}_{0}$ dan $\mathrm{H}_{1}$

Keterangan:

(KO) : tanpa perlakuan injeksi dan terapi

(K-) : pemberian pelarut Kontrol positif

$(\mathrm{K}+) \quad$ : injeksi aloksan dosis $32 \mathrm{mg} / 200 \mathrm{~g}$ BB 
Dosis 1 (D1): pemberian terapi dosis $25 \mathrm{mg} / \mathrm{Kg} \mathrm{BB}$ Dosis 2 (D2): pemberian terapi dosis $50 \mathrm{mg} / \mathrm{Kg} \mathrm{BB}$ Dosis 3 (D3): pemberian terapi dosis $75 \mathrm{mg} / \mathrm{Kg} \mathrm{BB}$

Kemampuan ekstrak umbi binahong dalam menurunkan kadar glukosa darah tikus diabetes berkaitan dengan aktivitas biologis senyawa dalam umbi binahong. Salah satunya adalah flavonoid yang diduga mengembalikan sensitifitas reseptor insulin pada sel sehingga menurun kadar glukosa tersebut, selain itu flavonoid sebagai antioksidan yang dapat memperbaiki sel $\beta$ pankreas yang telah rusak akibat radikal bebas (Saleh, 2012). Umbi binahong juga mengandung senyawa saponin yang dimungkinkan berperan dalam menghambat aktivitas enzim $\alpha$-glukosidase, yaitu enzim yang bertanggung jawab pada pengubahan karbohidrat menjadi glukosa sehingga menurunkan kadar glukosa darah (Manoi, 2009).

Berdasarkan hasil uji Duncan diperoleh dosis $25 \mathrm{mg} / \mathrm{kg}$ BB yang bekerja secara maksimal dalam menurunkan kadar glukosa darah sehingga dosis $25 \mathrm{mg} / \mathrm{kg} \mathrm{BB}$ memperlihatkan efek hipoglikemik yang paling baik.

\section{Aktifitas SOD}

Pengujian pada aktifitas SOD ini radikal superoksida $\left(\mathrm{O}_{2}^{-}\right)$terbentuk selama aktifitas fisik berat, dimana radikal tersebut bersifat reaktif dan berbahaya bagi tubuh, sehingga radikal tersebut dinetralisir dengan enzim SOD dalam jaringan jantung dan akan mengoksidasi garam tetrazolium (berwarna kuning) yang terdapat dalam NBT menjadi formazan yang berwarna ungu. Adapun reaksi yang terjadi sebagai berikut pada Gambar 3.

Pada analisis ini enzim SOD (Superoksida dismutase) dalam sampel jantung akan berlomba dengan NBT untuk bereaksi dengan radikal superoksida sehingga menghambat pembentukan zat warna (dye).

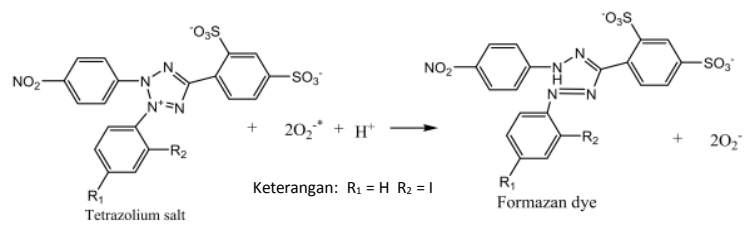

Gambar 3.Reaksi radikal superoksida dan NBT menghasilkan formazan (Ukeda et al, 1999)

Hasil pengujian aktifitas SOD ditunjukkan pada Tabel 3.

Tabel 3 Rerata aktivitas SOD (Superoksida dismutase)

\begin{tabular}{|c|c|}
\hline Perlakuan & Aktivitas SOD (u/ml) \\
\hline K O & $5,386 \pm 0,28$ \\
\hline K - & $5,219 \pm 0,2$ \\
\hline K $~$ & $4,358 \pm 0,27$ \\
\hline D1 & $5,511 \pm 0,12$ \\
\hline D2 & $5,247 \pm 0,37$ \\
\hline D3 & $4,942 \pm 0,28$ \\
\hline
\end{tabular}

Tiga kelompok terapi ekstrak umbi binahong mengalami peningkatan dibandingkan dengan kelompok positif yang lebih rendah. Hal tersebut terjadi karena kandungan aktif dalam umbi binahong bertindak sebagai antioksidan alami yang menghambat radikal bebas sehingga terjadi peningkatan aktivitas SOD. Salah satu golongan senyawa antioksidan tersebut adalah flavonoid. Flavonoid tersebut berperan sebagai scavenger radikal karena mampu menangkap radikal bebas dalam tubuh dengan adanya ikatan rangkap terkonjugasi dan atom $\mathrm{H}$ sebagai donor dari gugus hidroksil (-OH) fenolik pada saat bereaksi dengan radikal bebas (Retno, 2013).

\section{KESIMPULAN}

Hasil uji fitokimia umbi binahong meliputi flavonoid, alkaloid, tanin, saponin 
dan terpenoid, dimana eluen terbaik yang dihasilkan dari KLT analitik pada pemisahan senyawa flavonoid adalah butanol- asam asetat -air (4:1:5). Umbi binahong (Anredera cordifolia (Ten.) Steenis) memiliki aktivitas antidiabetes yaitu mampu menurunkan kadar glukosa darah serta pada peningkata aktifitas SOD (Superoksida dismutase) jantung tikus yang diterapi ekstrak dosis $25,50,75 \mathrm{mg} / \mathrm{kg} \mathrm{BB}$ berturut-turut $5,511 \mathrm{u} / \mathrm{ml} ; 5,217 \mathrm{u} / \mathrm{ml}$ dan $4,942 \mathrm{u} / \mathrm{ml}$. Dosis terbaik adalah $25 \mathrm{mg} / \mathrm{kg}$ BB.

\section{DAFTAR PUSTAKA}

Astuti, S.M. 2011. Skrining Fitokimia dan Uji Aktifitas Antibiotika Ekstrak Etanol Daun, Batang, Bunga dan Umbi Tanaman Binahong(Anredera cordifolia (Ten) Steenis). Fakultas Kejuteraan Kimia. Malaysia: Universitas Malaysia Pahang.

Gustaviani, R. 2006. Buku Ajar penyakit Dalam Jilid III Edisi IV: Diagnosa dan Klasifikasi Diabetes Mellitus. Jakarta: FKUI.

Lenzen, S. 2008. The Mekanism of alloxan and streptozotocin-induced diabetes.Diabetologia

Makalalag, I.W. Wullur, A. Adeanne dan Wiyono, W. 2013. Uji Ekstrak Daun Binahong (Anredera cordifolia (Ten) Steenis) Terhadap Kadar Gula Darah Pada Tikus Putih Jantan Galur Wistar ( Rattus norvegicus) yang diinduksi Sukrosa. Jurnal Ilmiah farmasi- UNISRAT. Vol 2. No. 01.

Manoi, Feri. Dan Ballitro, 2009. Binahong (Anredera cordifilia) sebagai obat. Warta Penelitian dan Pengembangan. Jurnal. Vol.15 No.1.hlm: 3-6.

Retno, A., Aulanni'am dan Prasetyawan, S. 2013. Potensi Ekstrak Rumput Laut
Coklat (Sargassumprismaticum) untuk Meningkatkan Aktivitas Superoksida Dismase (SOD) dan gambaran Histoplogi jaringan Hepar pada Tikus (Rattus norvegicus) Diabetes Melitus Tipe 1. Kimia Student Journal. Vol 2.No 1.hlm:414-420.

Saleh, C., Sitorus, dan Nursanti. 2012. Uji Hipoglikemik Ekstrak Etanol Umbi. Anredera cordifolia [Ten.] Steenis. Jurnal. Samarinda: Jurusan Kimia Fakultas MIPA Universitas Mulawarman.Vol 11. hlm: 96-99

Selawa, W., Runtuwene, M.R dan Citraningtyas, G. 2013. Kandungan Flavonoid dan Kapasitas Antioksidan Total Ektrak Etanol Daun Binahong (Anredera cordifolia (Ten) Steenis). Jurnal Ilmiah farmasi - UNSRAT. Vol 2. No.1.

Sherly R, Barlianto W dan Setyohadi R. 2013. Pengaruh Selenium (Se) Pada Model Tikus Putih (Rattus Norvegicus) dengan Pajanan Ovalbumin-Induced Allergic Asthma (OVA). Tugas Akhir, Fakultas Kedokteran Universitas Brawijaya Malang.

Szkudelski, k and Szkudelska. 2001. Streptozotocin Induces Lipolysis in Rat Adipocytes in Vitro. Department of Animal Physiology and Biochemistry, University of Agriculture, Poznań, Poland. Physiol. Res.51: 255-259.

Ukeda H, Kawana D, Maeda S dan Sawamura $\quad$ M. 1999. Spestrophotometric Assay for Superoxide Dismutase Based on the Reduce of Highly Water-soluble Tetrazolium Salts by XanthineXanthine Oxidase. Biosci Biotechnol, Biochem., 63 (3), 485488. 